\title{
A Two-Mode Digital Pressure Meter Equipped With An Automatic Leak Test Using MPX5050gp And MPXv4115vc6u Sensors
}

\author{
Fita Florensa Rooswita, Triana Rahmawati, Syaifuddin \\ Department of Electromedical Engineering Poltekkes Kemenkes, Surabaya \\ Jl. Pucang Jajar Timur No. 10, Surabaya, 60245, Indonesia
}

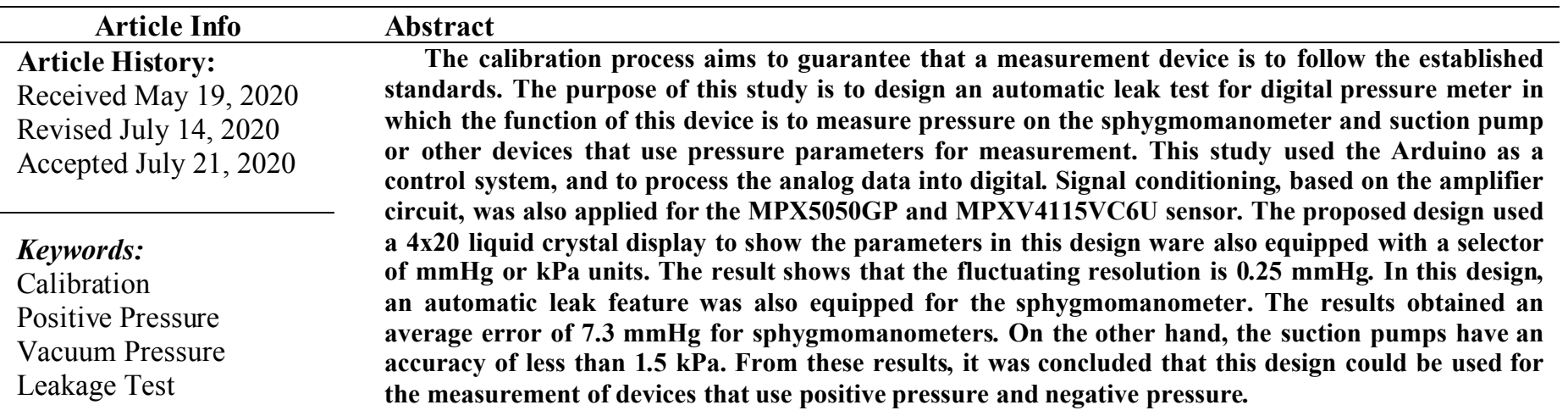

\section{Corresponding Author:}

triana@poltekkesdepkes-sby.ac.id, Department of Electromedical Engineering Poltekkes Kemenkes, Surabaya
This work is an open-access article and licensed under a Creative Commons Attribution-ShareAlike 4.0 International License (CC BY-SA 4.0).

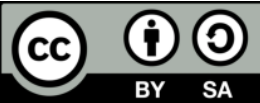

\section{INTRODUCTION}

Sphygmomanometers have several observer error variables and devices used, which make measurement error problems and become a discussion during public health [1]. Discussions such as the correct method, the most common errors, the size, and the proportion of fixed cuffs in the search for more reliable measuring devices that show patients' true blood pressure [2]. The results of blood pressure measurements carried out with mercury are different from the results of measurements made with a digital sphygmomanometer. With differences in measurement results, it is necessary to identify blood pressure gauges. The results of blood pressure measurements must be done correctly, this is because of health concerns and patient safety. Errors in blood pressure measurement can be caused by human error or the function of the device itself whose accuracy has exceeded the allowable threshold (Standard error of up to 3 $\mathrm{mmHg}$ ) [3]. The maximum error permitted for blood pressure measurements anywhere on the scale range should be $\pm 0.4 \mathrm{kPa}$
$( \pm 3 \mathrm{mmHg}$ ) in the case of first time verification and $\pm 0.5 \mathrm{kPa}$ ( $\pm 4 \mathrm{mmHg}$ ) for the sphygmomanometer used [4].

The design of this DPM has been carried out by several previous researchers, Junia Dyah Permata Wibisono in 2017 made this module but only with one mode, namely vacuum pressure [5]. Then in 2018 Yosep Kurniawan made a twomode DPM module but the weakness of this module lies in the measurement unit only one parameter, the use of the same negative sensor MPXV4115 but the difference in positive pressure [6]. Then in 2019 there were two people who made the DPM module namely Ryan Nur Rokhman and Abdul Cholid who made the same DPM in two modes and still used one measurement parameter, $\mathrm{mmHg}$ [7] [8]. Inadequate sphygmomanometer treatment and calibration are common causes of systematic errors in blood pressure measurement. The only way to reduce systematic errors is to use correct measurement techniques and instruments that are well maintained and calibrated [9]. Suction Pump is a medical 
device that functions to suck out liquids that are not needed by the body in the operation process, such as blood, stomach contents, and so on. Then the liquid that is sucked is collected in a container. The working principle of the Suction Pump is that the motor will rotate along with the suction fan so that it can suck the fluid in the patient's body through the suction hose which is connected through a tube and filter [10].

Based on what has been described, the researcher will add the measurement unit parameters into two, $\mathrm{mmHg}$ and $\mathrm{Kpa}$, and will add a leakage test automatically, because tensimeter calibration requires a leak test because it is very important to know whether tensimeter is still feasible or not. In addition to the leak test, there are 2 measurement times, namely 60 seconds and 5 minutes, this refers to Permenkes.

\section{MATERIALS AND METHODS}

\section{A. Experimental Setup}

This study uses a sphygmomanometer and suction pump subject that has been calibrated and the data is taken once

\section{B. Materials and Device}

In this study using MPX5050GP sensor made by Freescale semiconductor in Texas America for positive pressure reading while for negative pressure reading using MPXV4115VC6U sensor made by Motorola Semiconductor product in America, In both sensors an appropriate capacitor was added with the datasheet on the sensor. in processing the output of the sensor using ARDUINO NANO ATMega 328 on pins A1 and A2, before processing the output first goes to the buffer circuit, for the power supply in this module uses 2 lithium polymer batteries, and all results will be displayed on a $4 \times 20$ character LCD.

\section{Experiment}

In this study, researchers conducted a calibration of the sphygmomanometer and suction pump using a module that has been made, namely two-mode DPM with 2 units of measurement, namely $\mathrm{mmHg}$ and $\mathrm{Kpa}$

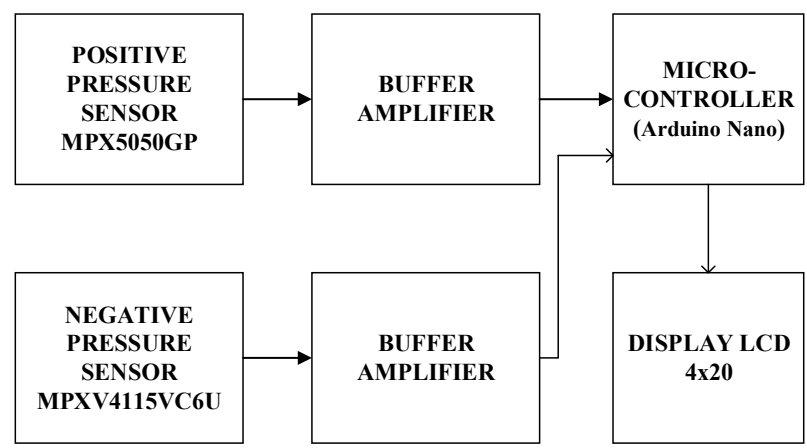

Fig 1. The diagram block of the Pulse Oximetry

\section{The Diagram Block}

When the ON / OFF button is pressed, the voltage from the battery will supply the microcontroller and pressure sensor so that the device is ready to use. Then, the LCD screen displays the selection mode between positive pressure and negative pressure. When the Positive Pressure is working, the MPX5050GP sensor is active then the sensor output is forwarded to the buffer circuit and then processed by Arduino nano ATMega 328, just as if the negative pressure is working then the active sensor is MPXV4115VC6U then the sensor output is forwarded to the buffer circuit and processed on the buffer circuit Arduino nano ATMega 328, from all the results will be displayed on the character LCD (Fig. 1).

\section{E. The Flowchart}

The flow chart shows the course of the program reading device and the beginning of the end series. In this module there are two units of measurement, namely mmHg and Kpa.

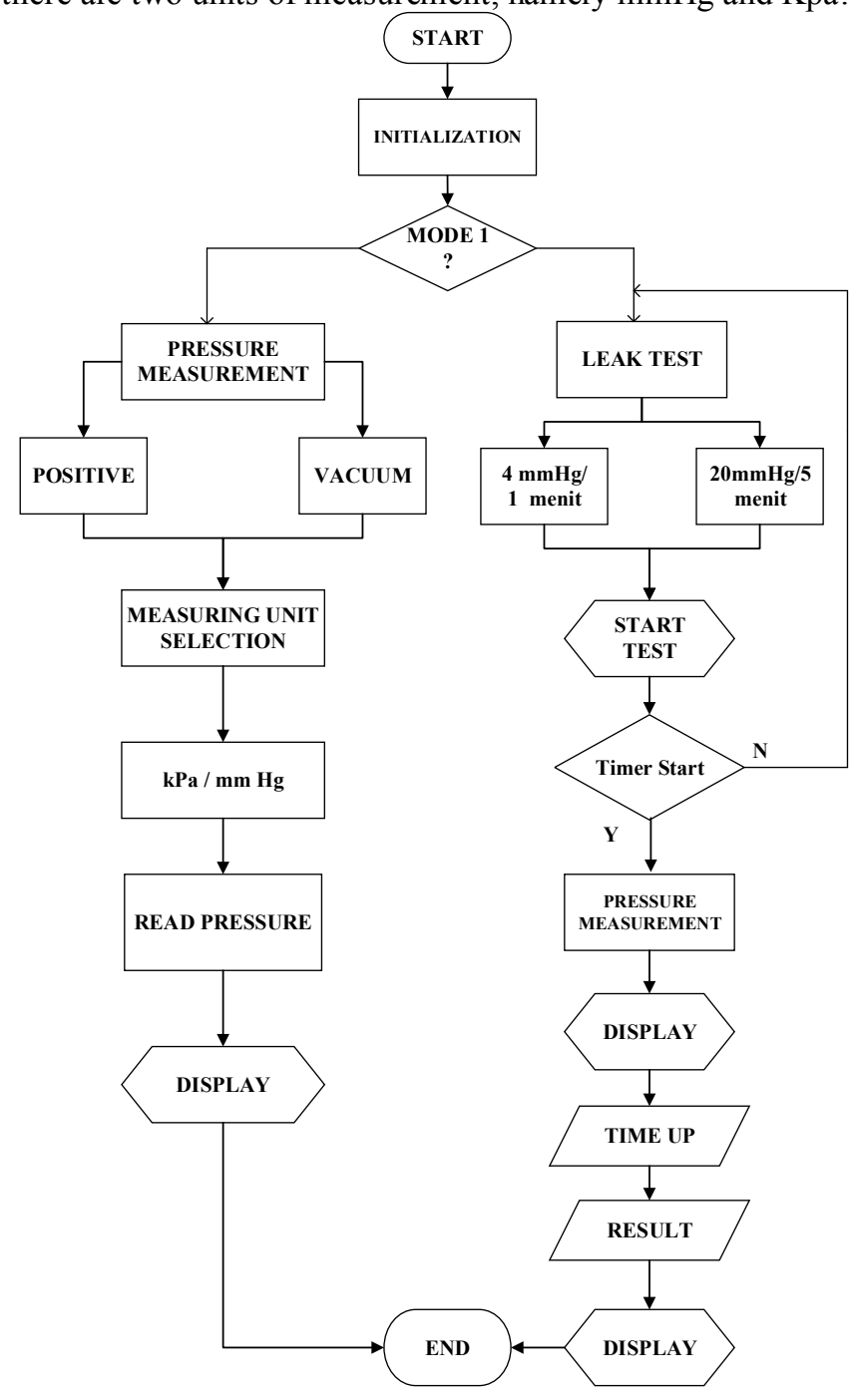

Fig 2. The Flowchart of the Arduino Program

There is also a selection of leak tests for the sphygmomanometer after the selection is complete and pushbutton enter is pressed then the sensor will start reading. The following is a flowchart of the module (Fig. 2). 


\section{F. Circuit}

\section{1) Circuit of minimum system}

Analog data from the sensor is converted to digital data by Arduino via PIN A0 (for positive pressure) and PIN A1 (for negative pressure). The $4 \times 20 \mathrm{LCD}$ is used to display the pressure data that has been taken. UP and DOWN selection buttons are used to select the desired pressure positive or negative pressure besides this button is also used for the selection of $\mathrm{mmHg}$ or Kpa units. When logic is high, the program will detect the presence of input on a digital pin and then the program will run a reading mechanism on the input pin variable which is processed in such a way that the equation is obtained so that a positive or negative pressure reading occurs (Fig. 3).

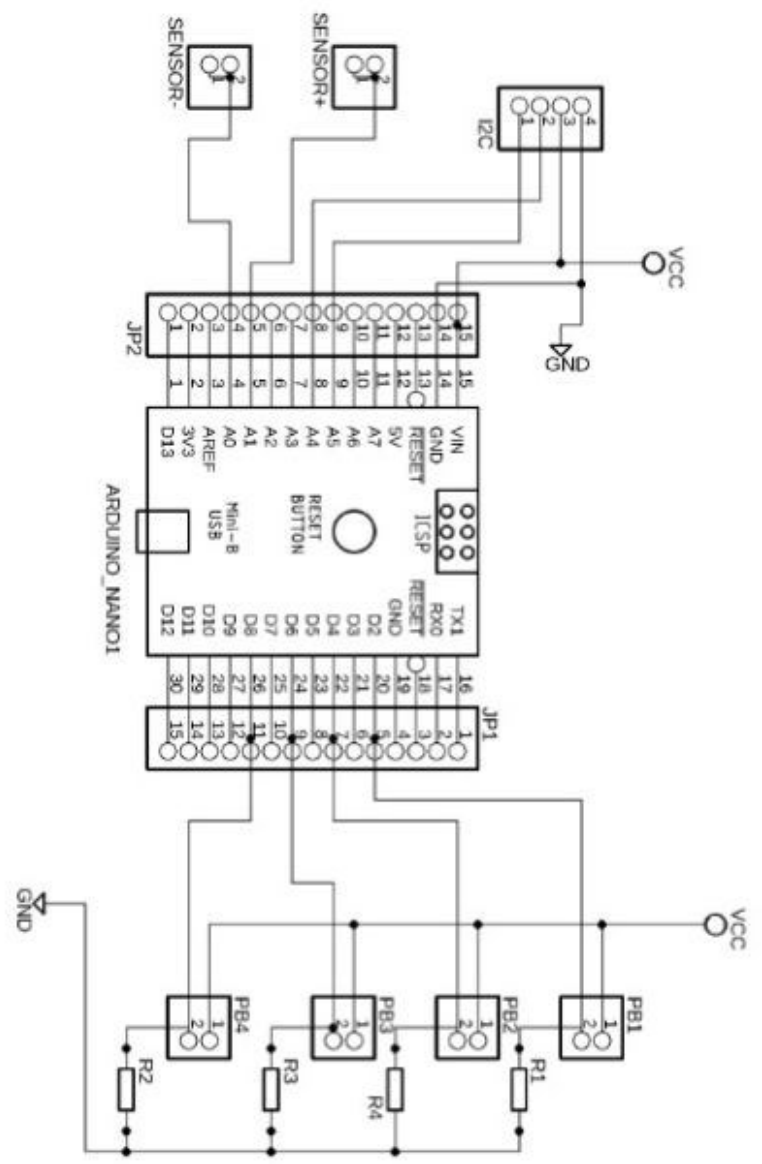

Fig 3. Circuit of minimum system

\section{2) Circuit of $M P X 5050 G P$}

Input in the sensor circuit is pressure, the pressure captured by the sensor will be converted to a voltage (Fig. 4). In this type of sensor, the results of the ratio of pressure and voltage are directly proportional so that the resulting value is higher the pressure the higher the output results.

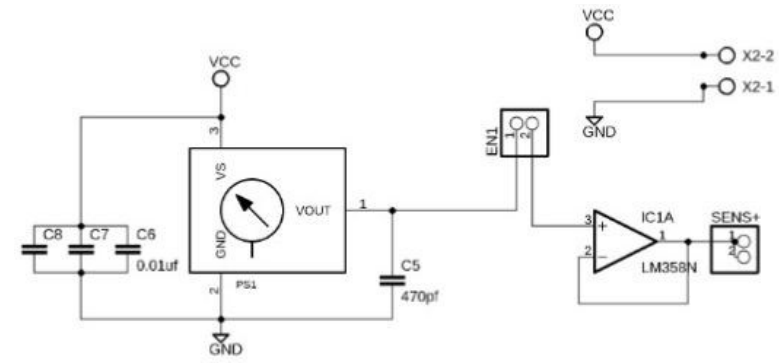

Fig 4. Circuit of MPX5050GP

\section{3) Circuit of $M P X V 4115 \mathrm{VC} 6 \mathrm{U}$}

Input in the sensor circuit is pressure, the pressure captured by the sensor will be converted to a voltage (Fig. 5). In this type of sensor, the results of the ratio of pressure and voltage are directly proportional so that the resulting value is higher the pressure the higher the output results.

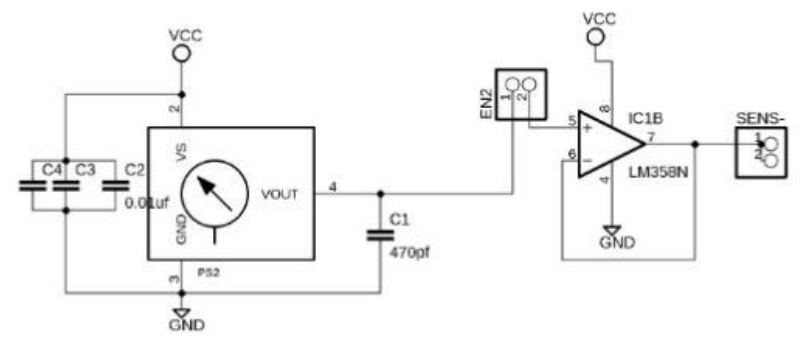

Fig 5. Circuit of MPXV4115VC6U

\section{RESULTS}

In this study using a sphygmomanometer and suction pump as a comparison and module parameters, and the units taken in this study are $\mathrm{mmHg}$ and $\mathrm{KPa}$ for positive or negative pressure.

\section{A. Results of DPM Design}

A sphygmomanometer design was shown in Fig. 6. It is equipped with LCD $4 \times 16$ character and four button for user interaction.

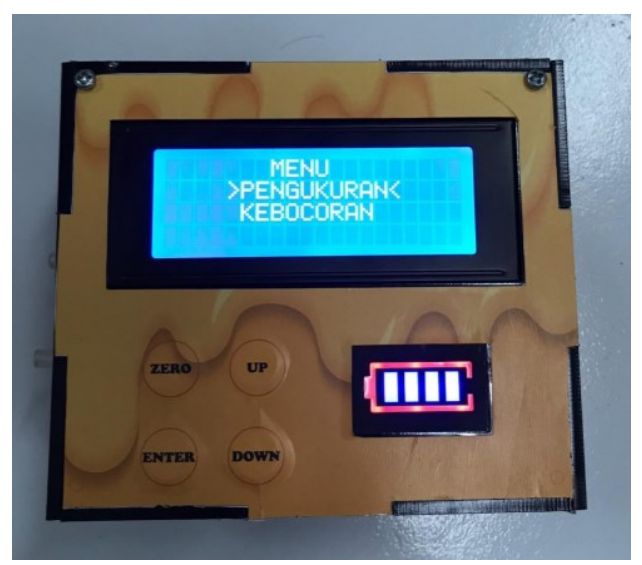

Fig 6. Results of modul DPM 


\section{B. Program listing for positive pressure sensor readings}

\begin{tabular}{|c|}
\hline 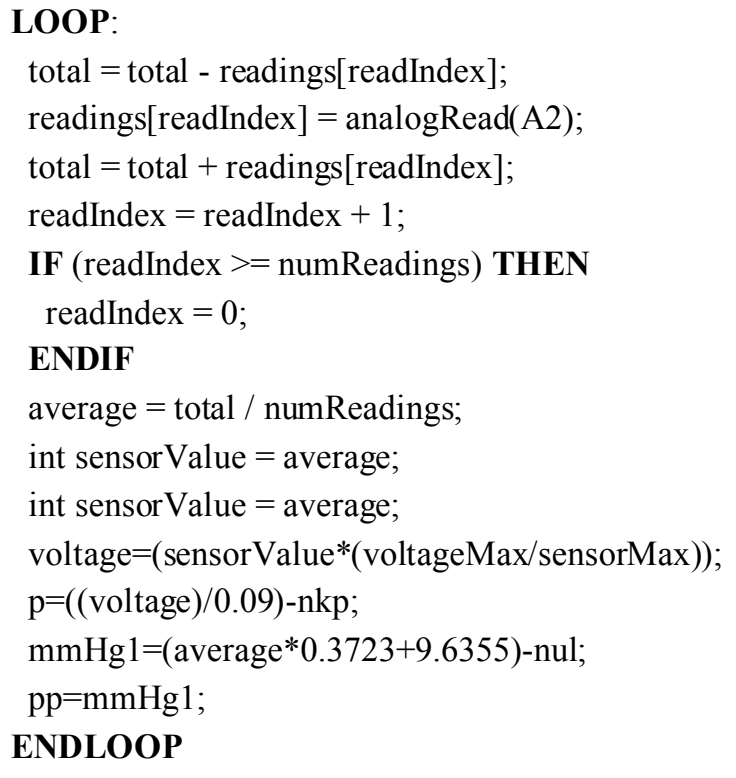 \\
\hline
\end{tabular}

The above program functions as initialization of a positive pressure reading on the MPX5050GP sensor from the microcontroller and also as an ADC smoothing program on the sensor with evenly distributed $10 \mathrm{ADC}$ reading data.

C. Progam listing for negaive pressure sensor readings

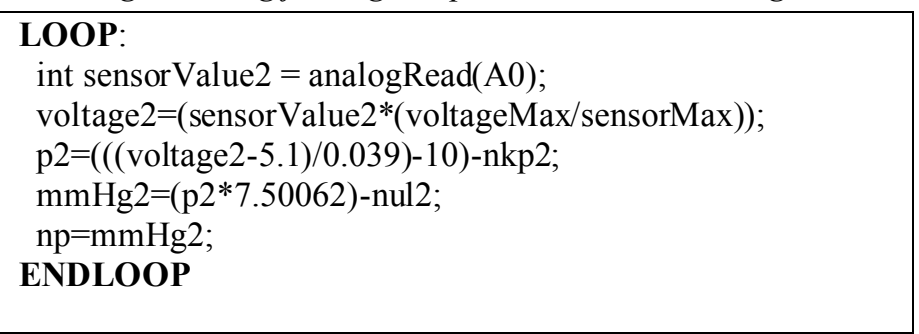

The above program is a program for TFT LCD and sensor initialize MAX30102 to be able to communicate with the microcontroller. TFT LCD with 9600 baud rate and sensor using a baud rate 115200 .

\section{Listing program for Display Menu}

\section{WHILE (1)}

lcd.setCursor(7, 0); //pengaturan tampilan

lcd.print("MENU");

lcd.setCursor $(4,1)$;

lcd.print(">PENGUKURAN<");

lcd.setCursor $(5,2)$;

lcd.print("KEBOCORAN");

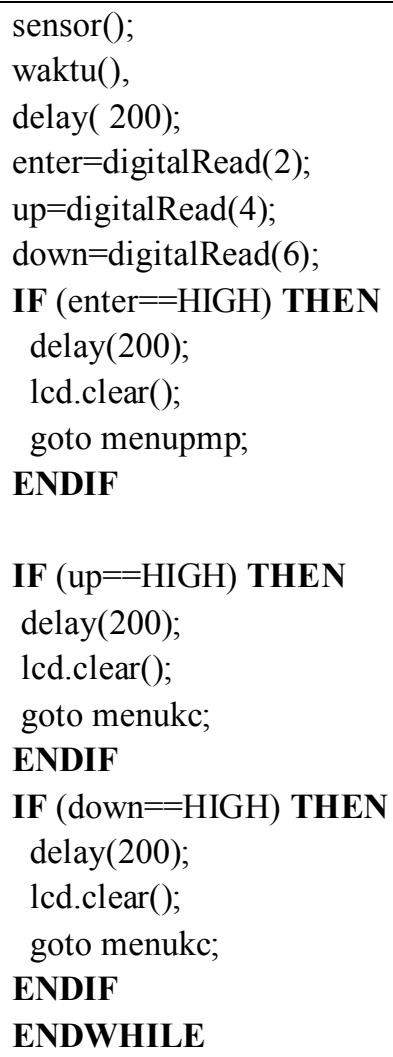

The menu program above there are various kinds according to needs and in the program created there are menus for each mode, namely a menu for measuring positive, negative, $\mathrm{mmHg}$, $\mathrm{kPa}$, and leak tests.

\section{E. Listing program for Timer}

LOOP:
IF ( state==1) THEN
unsigned long waktu $=$ millis( $)$;
ENDIF
IF (waktu - waktusekarang $>1000$ )
$\quad$ waktusekarang $=$ millis $($ );
detik++;
ENDIF
IF (detik $>$ 59) THEN
menit $++;$
detik $=0$;
ENDIF
IF (menit $>$ 59) THEN
menit $=0$;
ENDIF




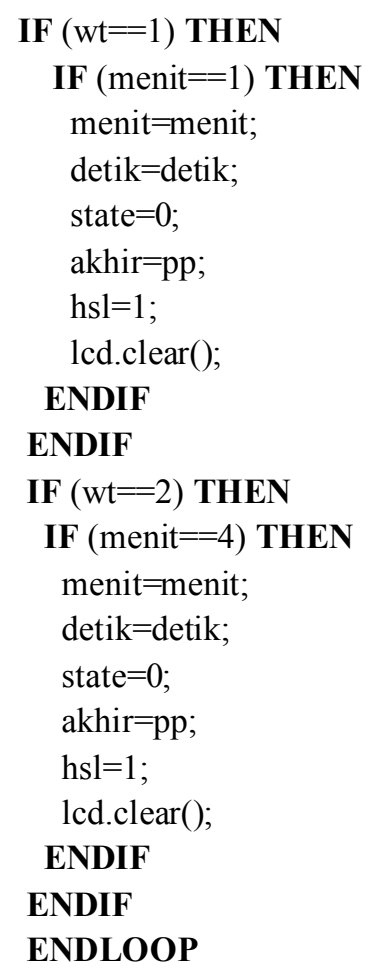

A timer program using the system counter on millis (). With millions of reading for 1000 times, a value of 1 second will be obtained and a reading of more than 60 seconds will produce 1 minute. The conditions in the last line are used to stop the timer.

\section{F. Measurement results chart}

The device was calibrate using standard pressure meter to show the accuracy of the machine. The measurement was performed for positive, negative and difference unit $(\mathrm{kPa})$ as shown in Fig 7, Fig. 8 and Fig. 9, respectively.

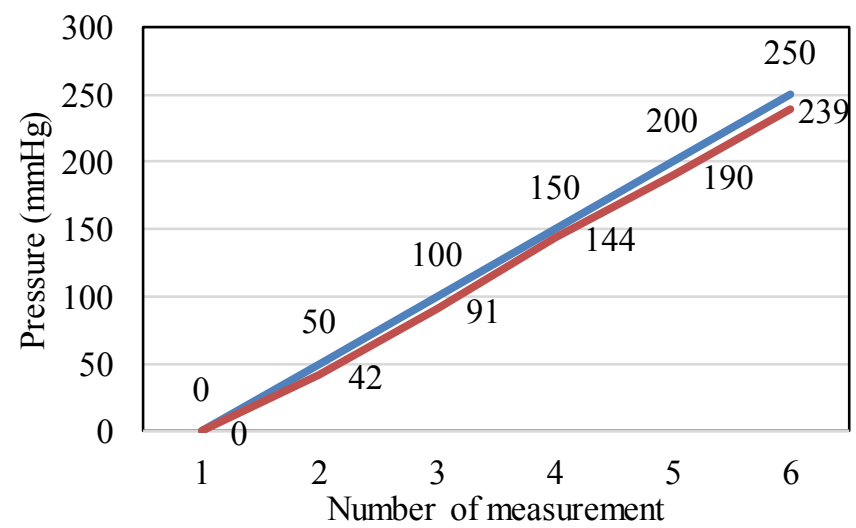

Fig 7. Measurement chart on the sphygmomanometer $(\mathrm{mmHg})$. The blue line is standard and the red line designs.

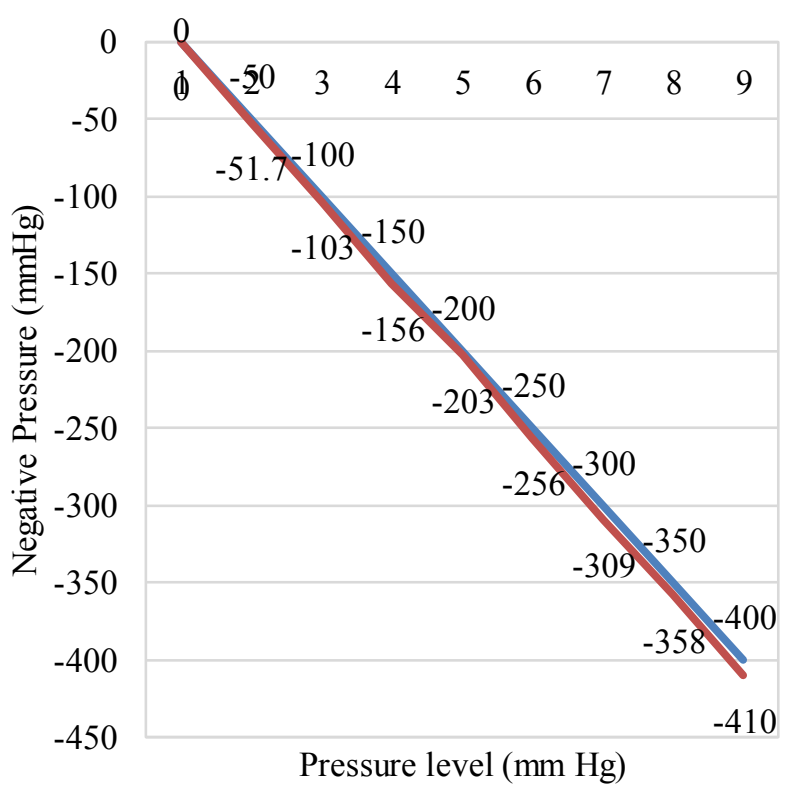

Fig 8. Measurement chart on the suction pump ( $\mathrm{mmHg})$. The blue line is the standard pressure and the red line is the design.

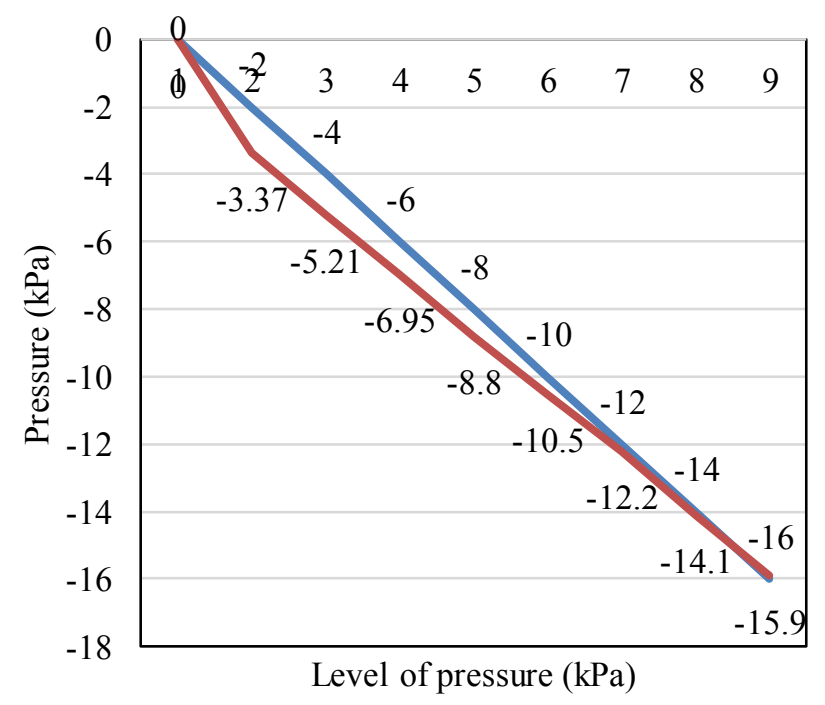

Fig 9. Measurement chart on the suction pump (Kpa). The blue line is the standard pressure and the red line is the design.

G. $\mathrm{DPM}$ measurement table with sphygmomanometer
(mmHg) The measurement result from design and standard are evaluate to show the accuracy of the device. The error was the difference between the standard and design as shown in TABLE I, TABLE II and TABLE III. 
Journal of Electronics, Electromedical, and Medical Informatics (JEEEMI)

Vol. 2, No. 2, July 2020, pp. 80-85

DOI: 10. 35882/jeeemi.v2i2.7

TABLE I. MEASUREMENT CHART ON THE SPHYGMOMANOMETER (MMHG)

\begin{tabular}{ccc}
\hline $\begin{array}{c}\text { Pressure } \\
(\mathrm{mmHg})\end{array}$ & $\begin{array}{c}\text { Measurement } \\
\text { result }\end{array}$ & $\begin{array}{c}\text { Error } \\
(\mathrm{mmHg})\end{array}$ \\
\hline 0 & 0 & 0 \\
50 & 42 & 8 \\
100 & 91 & 9 \\
150 & 144 & 6 \\
200 & 190 & 10 \\
250 & 239 & 11 \\
\hline
\end{tabular}

\section{H. DPM measurement table with Suction Pump (mmHg)}

TABLE II. MEASUREMENT CHART ON THE SUCTION PUMP (MMHG)

\begin{tabular}{ccc}
\hline $\begin{array}{c}\text { Pressure } \\
(\mathrm{mmHg})\end{array}$ & $\begin{array}{c}\text { Measurement } \\
\text { result }\end{array}$ & $\begin{array}{c}\text { Error } \\
(\mathrm{mmHg})\end{array}$ \\
\hline 0 & 0 & 0 \\
-50 & -51.7 & 1.7 \\
-100 & -103 & 3 \\
-150 & -156 & 6 \\
-200 & -203 & 3 \\
-250 & -256 & 6 \\
-300 & -309 & 9 \\
-350 & -358 & 8 \\
-400 & -410 & 10 \\
\hline
\end{tabular}

I. DPM measurement table with Suction Pump (Kpa)

TABLE III. MEASUREMENT CHART ON SUCTION PUMP (KPA)

\begin{tabular}{ccc}
\hline $\begin{array}{c}\text { Pressure } \\
(\mathrm{mmHg})\end{array}$ & $\begin{array}{c}\text { Measurement } \\
\text { result }\end{array}$ & $\begin{array}{c}\text { Error } \\
(\mathrm{mmHg})\end{array}$ \\
\hline 0 & 0 & 0 \\
-2 & -3.37 & 1.37 \\
-4 & -5.21 & 1.21 \\
-6 & -6.95 & 0.95 \\
-8 & -8.80 & 0.80 \\
-10 & -10.5 & 0.5 \\
-12 & -12.2 & 0.2 \\
-14 & -14.1 & 0.1 \\
-16 & -15.9 & 0.1 \\
\hline
\end{tabular}

\section{DISCUSSION}

In the DPM module that is made using positive and negative pressure measurements, this module has 2 units of measurement namely $\mathrm{mmHg}$ and $\mathrm{kPa}$ for the measurement of the sphygmomanometer and suction pump, the disadvantage of the module being made is that the power in the battery runs out quickly.

\section{CONCLUSION}

Overall this study can conclude that for positive pressure data taken only once and can be seen error values if averaged each measurement obtained a value of $7.3 \mathrm{mmHg}$. And for negative pressure with $\mathrm{mmHg}$ units the higher the value taken; the error generated on the device is also greater. Whereas at the negative pressure the $\mathrm{kPa}$ unit the higher the value has taken the smaller the error produced.

\section{REFERENCES}

[1] Permenkes, "Peraturan Menteri Kesehatan Republik Indonesia Nomor 54 Tahun 2015," Permenkes, vol. 151, pp. 10-17, 2015.

[2] P. C. Silva et al., "Analysis of Mercury Sphygmomanometers in A Hospital School-Analysis of Mercury Sphygmomanometers," vol. 5, no. 1, pp. 697-700, 2018.

[3] A. Pudji, "Design of the Digital Pressure Meter with Thermohygrometer," TEKNOKES vol. 7, no. 9, pp. 35-39, 2017.

[4] I. Organization And O. L. Metrology, "Oiml R 63," vol. 2002, pp. 1-8, 2002.

[5] H. A. Pudji, “ Digital Pressure Meter ( DPM ) Vacum Pressure,”, TEKNOKES, Vol. 12 No 1, 2017

[6] E. yosep kurniawan, syaifudin, "Dpm dua mode," TEKNOKES, Vol 12, No 1, 2018.

[7] M. Ryan, N. Rokhman, B. G. Irianto, and H. G. Ariswati, "Digital Pressure Meter Tensimeter Dan Suction Pump," vol. 12, no. 1, pp. 1-4, 2019.

[8] A. C. Ridwan and H. G. Ariswati, "DPM Two Modes Equipped With Temperature And Humidity," Indonesian journal of electronics, electromedical engineering, and medical informatics, vol. 2, no. 1, pp. $1-5,2020$.

[9] M. J. Turner, "Sphygmomanometer calibration Why, how and how often ?," no 1. November 2007, 2018.

[10] M. Hilmi, A. Pudji, I. D. Gede, and H. Wisana, "Suction Pump Transport," Journal of electronics, electromedical engineering, and medical informatics, vol 1, no 1. pp. 1-8. 